\title{
Second generation from refugee backgrounds in Europe
}

\author{
Milena Chimienti ${ }^{1 *}$ (D) Alice Bloch ${ }^{2}$ (D) Laurence Ossipow ${ }^{1}$ and Catherine Wihtol de Wenden ${ }^{3}$ (D)
}

\author{
* Correspondence: Milena. \\ Chimienti@hesge.ch \\ ${ }^{1}$ University of Applied Sciences and \\ Arts Western Switzerland - School \\ of Social Work, HESSO-GE/HETS, 28, \\ rue Prévost-Martin, P.O. Box 80, \\ 1211 Geneva 4, Switzerland \\ Full list of author information is \\ available at the end of the article
}

\begin{abstract}
This introduction to the special issue provides a critical state-of-the-art of the literature on second-generation migrants which has hitherto subsumed the case of the children of refugees. It highlights the theoretical and methodological orientations taken by the literature and examines the main findings on the second generation's social, educational, economic, cultural and inter-generational lives, before turning to the few findings available on conditions and performances of children of refugees. The editorial concludes by suggesting gaps in our knowledge and areas for future research.

Keywords: Refugees, Second generation, Youth, Europe
\end{abstract}

\section{Introduction}

The immigrant second generation represents a substantial proportion of the population in the United States and Europe: circa 11\% in the US and 34.3\% in Europe. ${ }^{1}$ Most of the literature on the children of migrants born in Europe or the US argues that the economic, social and political lives of second-generation individuals are different to those of their peers with no migratory background and to those of their migrant parents. This special issue discusses a third hypothesis which assumes that the experiences of second-generation migrants from refugee backgrounds might be different from those of other second generation members because of the violence and/or trauma that their parents may have suffered from and the limited rights that some have been subjected to as asylum-seekers when they arrived in the receiving country. However, rather than being considered in the light of the particularities of their refugee background, the children of refugees have been mainly subsumed into the research evidence on the experiences of ethnic minorities as a whole. This means that studies that focus on minorities more generally miss important formative experiences that could potentially impact on the experiences of those growing up within the context of families in which parents are or have been refugees.

Addressing this gap in the literature, this special issue aims to identify some of the effects of coming from a refugee background on life trajectory. This is a timely issue because refugees arriving in Europe have become increasingly diverse and their number as well as the number of their European-born children has increased significantly since the 1960s. In fact, the numbers of asylum-seekers arriving in Europe increased markedly from the 1990s onwards, which means that there are more and more

(C) The Author(s). 2019 Open Access This article is distributed under the terms of the Creative Commons Attribution 4.0 International License (http://creativecommons.org/licenses/by/4.0/), which permits unrestricted use, distribution, and reproduction in any medium, provided you give appropriate credit to the original author(s) and the source, provide a link to the Creative Commons license, and indicate if changes were made. 
children growing up within the context of refugee families who may have experienced a precarious legal status and punitive regimes. In view of the high number of refugee families who came, over the past decade, from the Middle East and, among other countries, from Syria, the education of their children is a particularly important question.

Our aim is to generate an understanding of the specific situations, aspirations, social and economic lives, identities and transnational linkages of those who have grown up in Europe as second generation from refugee backgrounds. We start by presenting some of the main theoretical discussions on second-generation migrants and by presenting some empirical findings on their integration in Europe.

\section{'Second-generation migrants': a category of exclusion?}

We purposely use the term 'second generation' in the papers of this special issue in order to describe the European born children of refugees. The notion 'second generation' underlines the fact that this group is frequently not seen as belonging to the country in which they were born and in which they grew up; persons of this group are often still perceived as foreigners and sometimes discriminated against on those grounds. In other words, the category of 'second generation' can be a description as well as a marker of their exclusion (Wihtol de Wenden, 2005). Nevertheless, most members of this group have the citizenship of their country of birth - a status received automatically in countries using the principle of jus soli ('right of the soil'). Those living in countries which follow the principle of jus sanguinis ('right of blood') have to take a test in order to get the citizenship (in the sense of nationality see Gagné \& Neveu, 2009).

The category 'second generation' was introduced and became popular in Europe, both in common discourse and by scholars, in regards to the precarious situations of the descendants of migrants in the residence country and to their putative lack of integration. The category was first used in the 1970s in relation to the right of former guestworkers to reside permanently, for example Italians in Switzerland and Turks in Germany, as well as in relation to the large-scale migration of Black and Asian Commonwealth citizens to the UK. The increase of the number of migrants and their settlement correlated with the economic turmoil that occurred in the 1970s provided fertile ground for the racialisation of issues such as employment, education and housing (Solomos, 1986, 2003). At that time, the category 'second generation' and the term 'integration' both highlighted the colonial and assimilationist perspectives towards migrants which had long-term impacts, as illustrated by the difficulty these countries had in considering the descendants of migrants born on their soil as citizens (Wihtol de Wenden, 2005). The contradictory status has become especially obvious in countries like Switzerland which had adopted the principle of jus sanguinis (right of blood). Here the children or even grandchildren (third generation) who did not naturalise are still recorded as foreigners, as the access to citizenship and Swiss nationality does not happen automatically. In France and the UK, where children of migrants automatically receive both citizenship and nationality of the residence country when they are 13 years (France) ${ }^{2}$ and 18 years (UK) ${ }^{3}$ old, the category rather defines an ethnic and problematic minority; in France this group simply disappears statistically. 
Against this problematic background of the category 'second generation', in several countries of immigration the 1980s and 1990s marked a moment of growing visibility and claims by the second generation. The will to re-appropriate the problem and redefine themselves was clearly articulated. This was a time of mobilisation and creation of different associations which led some groups to position themselves politically as a 'social movement', an 'ethnic lobby' or just 'new citizens' (Wihtol de Wenden, 2005). Some leaders of this movement became emblematic figures - for instance, in France, Harlem Désir from SOS Racisme and Arezki Dahmani from France Plus or, in Germany, the lawyer Seyran Ateş.

This overview shows that the category of 'second generation' has not represented, in its general imaginary, the specific case of the children of refugees. Most often, it referred to either the children of guestworkers or the children of migrants from former colonial countries. This means that second-generation migrants from refugee backgrounds have been subsumed within the broader analysis of the second generation by both common discourse and scholars - probably also because, in the public opinion, their situation was not seen as specific until increasing numbers of adults born in Europe from refugee backgrounds could be observed.

The 2000s marked the beginning of a third phase. Among the second generation we found attitudes of 'disillusionment' because of the lack of political recognition and of communitarian 'withdrawal' reacting to ongoing discrimination (Wihtol de Wenden, 2005). The 2000s also constituted a time of recognition in the sense that this category covers very different members, including those with an asylum background - who are also diverse. The children of refugees derive from heterogeneous socio-economic, religious, educational, political, cultural and ethnic backgrounds. What they have in common are parents who fled persecution in their country of origin and that they were born in another country than their parents. This can lead to different kinds of treatment in the country of birth and to the formation of additional relationships via differing attachments with the ancestral homeland of their parents and the current country of residence (Thurairajah, 2017, p. 116). Today there might be more consciousness of the diversity among the second generation related to their profile and living conditions (Cattacin, Fibbi, \& Wanner, 2016); access to citizenship in Europe might become more a matter of individual economic, political and social capital than of ethnicity (Faist, Schmidt, \& Ulbricht, 2016).

In summary, the notion 'second generation' appears problematic. It raises debates towards the socially constructed character of this category. ${ }^{4}$ Scholars, using the terminology of second-generation refugees take the risk of naturalising a category that does not exist and should be avoided in this sense. On the other hand, this notion helps to highlight and examine a particular experience; in this sense, it is useful (Bolzman, Bernardi, \& Le Goff, 2017).

\section{Studies of the second generation: key issues and concepts}

The literature on the second generation has a long tradition in the US. The first studies on the second generation appeared in the 1930s and 1940s and focused on the identity of the descendants of Japanese (Smith, 1928) or Italian immigrants (Child, 1943), relying on the earlier works of the Chicago School of Sociology and its peers (Park \& Burgess, 1921/1970; Thomas \& Znaniecki, 1918). In the 1990s, interest in the second 
generation became a major area of research and scholarship (Gans, 1992; Portes \& Rumbaut, 2001; Portes \& Zhou, 1993). This academic work led to large research programmes being set up in the US and more recently in Europe that have contributed to the deepening of knowledge on contemporary second generation behavior, experiences, economic and social lives. ${ }^{5}$ The focus of the US studies was on group analysis whilst European research focused more on the impact of the political, historical and educational contexts of each country on migrants' inclusion (Cattacin et al., 2016).

Central to all this research, however, is the question of integration. What form does the second generation's social and economic mobility take compared to that of their parents and peers who do not have a migratory background? What are the factors that explain their upward or downward mobility? These studies on the second generation focused on their social, educational, economic, cultural and inter-generational lives. More-recent research also explores feelings of belonging and identity.

The notion of integration: from an assimilation and citizenship approach to a diversity and institutional approach

Two major theories have orientated studies on integration. First the linear assimilation theory defined by the Chicago School of Sociology (Gordon, 1964; Park \& Burgess, 1921/1970) which argued for a straightforward upward mobility in education and occupation. Traditionally the assimilationist perspective explained integration through the lens of migrants' characteristics and cultural explanations but also assumed the absence of structural and institutional barriers such as immigration status and discrimination. Classical assimilation assumed that socio-economic integration was correlated with socio-cultural integration.

This model was criticised in the 1990s by Alejandro Portes and his colleagues (Portes \& Rumbaut, 2001; Portes \& Zhou, 1993), who emphasised the structural determinants of integration. As an alternative, they proposed the concept of 'segmented assimilation', which argues that different outcomes are possible for the second generation: they may experience classical assimilation, downward mobility or a combination of upward mobility with biculturalism (Portes \& Rumbaut, 2001; Portes \& Zhou, 1993).

In response to this approach, Alba and Nee (2003) revived the linear assimilationist theory predicting that most second-generation migrants will experience upward mobility and integration. The difference with the segmented assimilation theory is that, for them, there is no or little evidence of 'downward assimilation' nor of the beneficial effect of ethnic community on integration. They are, however, also skeptical towards a too straightforward assimilationist theory and their norms and prescriptions, arguing that assimilation is not a duty. Another key difference with segmented assimilation theory concerns the determinants of second generation mobility. For Alba and Nee (2003) assimilation will blur the structural differences: both first and second generation will follow a similar path to upward mobility. In contrast, for Portes and his colleagues the non-white racial status and economic changes will affect both first and second generation mobility; as a consequence, maintaining ethnic distinctiveness in the host society might help integration, compensating - through the help of the community - for the barriers of the wider societal context. At present, several contemporary studies in both the US and Europe find little evidence of second generation downward assimilation 
(Boyd, 2002; Farley \& Alba, 2002; Hirschman, 2001; Kasinitz, Mollenkopf, Waters, \& Holdaway, 2008; Smith, 2003; Waldinger, 2007; Waldinger \& Feliciano, 2004) or the negative role of community on mobility (Thomson \& Crul, 2007, p. 1036).

The empirical reality is that the children of migrants have varied trajectories; experiences and outcomes can vary and are contingent according to the segment of society into which they are being incorporated (Greenman \& Xie, 2008; Kroneberg, 2008). In short, some may be 'assimilated' into a racial or ethnic minority status that entails systematic disadvantages compared with society as a whole. The more contemporary theoretical approaches recognise the dynamic and situational character of integration.

Two other theories condense research differences concerning integration: the 'citizenship approach' (Brubaker, 1992; Castles \& Miller, 2003; Joppke, 1999) and the 'institutional approach' (Crul \& Vermeulen, 2003, 2006). In the citizenship approach, the different integration outcomes among migrants are explained by the variations between the national models of integration. This approach assumes that national policies of integration determine the socio-economic position of immigrants and their children. The differences within the national welfare systems and migration policies which shape the models of integration are emblematic of the European dilemma described by Schierup, Hansen, and Castles (2006) - the dual crisis of the welfare state and of the nation. Some states use welfare restrictions to exclude and impoverish migrants and to limit family reunion (Castles, 2004).

In contrast, Crul and Vermeulen (2003) argue that national models of integration do not have a univocal effect on the socio-economic integration of the children of migrants as their educational and labour-market positions can be affected in diverse ways by national models of integration and the integration context (Crul \& Schneider, 2010). Institutional arrangements, as opposed to distinct national models of integration, offer better explanations for the different integration patterns of the children of immigrants across Europe (Crul \& Vermeulen, 2003). This means that educational systems and the different ways in which the transition to the labour market may take place are also important. This 'institutional approach' focuses the explanation of differences on the societal context instead of on migrants and their children. This corresponds to the shift from an assimilationist perspective to a dynamic and contextual perspective.

Although these theoretical insights have led to many case studies and statistical analyses, the debated key differences still also need to be investigated in the light of the situation of the children of refugees. In the following we discuss selected existing research and scholarship in relation to education, employment, feelings of belonging and to remaining open questions. Reading these findings one should keep in mind the theoretical opposition mentioned above.

\section{Education}

The variable 'educational outcomes' between and within different groups is one of the main issues studied in the literature on the second generation. Research on their education has mostly focused on their school achievements, comparing them either to those of their parents or to the school achievements of those without a migratory background (Bolzman, Fibbi, \& Vial, 2003; Dustmann, Frattini, \& Lanzara, 2012). Empirical findings show that educational success is mostly determined by so-called individual factors, i.e. 
language skills or parents' educational and socio-economic levels (Bilgili, Huddleston, \& Joki, 2015; Dustmann et al., 2012; Feliciano, 2005). These individual determinants can, however, be balanced by structural and social factors. Cross-national research in Europe identifies institutional variations within the educational system as a factor shaping educational outcomes (Crul, Schneider, \& Lelie, 2012). Children with less-educated parents are particularly dependent on the educational system to balance this lack of capital (Portes \& Fernández-Kelly, 2008).

It is known that early access to school has a positive effect on the school achievements of children (Bilgili et al., 2015, p. 15). The same holds for mixed schools in terms of socio-economic and cultural backgrounds of the pupils. Moreover, the longer the time spent at school before selection to academic tracks, the greater the chances of high academic attainment among the children of migrants (Crul \& Schneider, 2009). Educational and family policies and a positive macro-economic context can balance out a lack of economic and cultural capital. Nevertheless, even then, equality in the opportunities for educational mobility is not guaranteed (Crettaz \& Jacot, 2014; Gomensoro \& Bolzman, 2016).

While the literature generally shows inter-generational upward mobility between the children's educational status and that of their parents, there is still an important gap when the second generation is compared with the population of native descent (Albertini, Knauth, Kraszewska, \& Thorogood, 2011). Therefore the differences between children's educational status and that of their parents should also be explored in the light of their integration in the labour market. What was seen only through intergenerational comparison at school as downward or upward mobility could appear, in fact, as horizontal mobility when taking into consideration the employment situation and comparing this with the rest of the population (Zhou \& Xiong, 2005).

The limited research available suggests that the European-born children of refugees can face greater disadvantage at school than second-generation children with a nonrefugee background (Bloch \& Hirsch, 2017; McBrien, 2005; Suárez-Orozco, Yoshikawa, Teranishi, \& Suarez-Orozco, 2011; Yoshikawa \& Kalil, 2011). This is due to their parents' pre- and post-migration experiences. Whether prior to migrating or during the journey, experiences of trauma can result in psychological and physical scars (Burnett \& Peel, 2001; Davies \& Webb, 2000; Heptinstall, Sethna, \& Taylor, 2004; Lustig et al., 2004). Refuges might have also experienced lengthy bureaucratic processes and the associated uncertainty of the future, coupled with the refugees' insecure immigration status, that can result in stress, a greater risk of ill health and therefore a lesser capacity to engage with their children (Alitolppa-Niitamo, 2004; Bloch \& Hirsch, 2017).

\section{Employment}

Regardless of migration histories and backgrounds, people from ethnic minority groups, when taken together, have higher rates of unemployment, earn less, are more frequently located in service-sector jobs and are less likely to be in managerial and professional positions than their white counterparts, both in Europe and the USA (Crul \& Mollenkopf, 2012; Heath \& Cheung, 2007). Of course such a macro analysis hides the diversity of experiences by class, gender and ethnicity. Among the second generation, those with the lowest educational levels are the most disadvantaged in the labour market (Crul \& Schneider, 2009). 
Strategies for improving the different employment outcomes of ethnic groups have focused on human capital deficits through skills training and education and, for refugees and new migrants, language acquisition or improvement. However, racism and discrimination are present in all aspects of the labour market (Bloch, Neal, \& Solomos, 2013). Referring to the UK, Heath and Cheung (2007) speak of 'ethnic penalty' - a contested term (see Virdee, 2010) - in order to conceive the intangible discrimination which, when all other factors are equal, still leads to worse labour market outcomes among people from ethnic minority groups. For Switzerland Fibbi, Lerch, and Wanner $(2006,2007)$ have shown that some members of the second generation (such as those from Turkish background) are subjected to discriminatory practices, such as lower income (Gomensoro \& Bolzman, 2016). In France the second generation shows disproportionately high rates of unemployment (Meurs, Pailhé, \& Simon, 2006; Simon, 2003), it experiences discrimination that prevents their access to high status, well paid occupations (Meurs et al., 2006; Silberman, Alba, \& Fournier, 2007). Nevertheless, compared to their parents, the second generation seems to perform far better in the labour market and to earn higher wages (Crul et al., 2012).

Refugees are more disadvantaged than others in the labour market, regardless of premigration skills and experiences (Bloch, 2008). Though their experiences are not uniform and some refugees do arrive with and/or accumulate economic capital (e.g. East African Asians in Britain, see Robinson, Andersson, \& Musterd, 2003), their disadvantages can persist. The consequence of disproportionately high levels of unemployment or of low pay, even when compared to other minorities, means that refugees have fewer resources with which to support their children at school which can impact on their educational outcomes. Yet, little is known about how those second-generation members of refugee background are experiencing the labour market once they reach adulthood.

\section{Transnational network and practices}

The concept of transnationalism is central to our understanding of the complexities of global migration. It focuses on how political, economic, social and cultural processes and activities extend beyond the borders of a particular state, how people can become multiple citizens with multiple identities and how individuals, communities and states operate within this fluid global context. There is a growing literature on transnationalism among the second generation. This literature suggests that the second generation is less transnational than the migrant generation or that it engages in different forms of transnationalism (Haikkola, 2011; Levitt, 2009), that transnationalism varies within and between generations, and that the second generation's emergence and participation in transnational ethnic communities require a more-nuanced and complex analysis than is usually the case.

Technological developments make transnational engagement possible for many and enable ties across different national states simultaneously (Portes, Guarnizao, \& Landolt, 1999), a phenomenon which Glick Schiller, Basch, and Blanc-Szanton (1995) have labelled 'simultaneous embeddedness'. The main factors that (re)produce these ties are communication, remittances, political involvement and travel (Audebert \& Doraï, 2010; King, Christou, \& Ahrens, 2011; Mckay, 2007; Wessendorf, 2007). Over the past few 
years, social scientists have also explored the relationship between transnational relations and integration (Amelina \& Faist, 2008; Crul et al., 2012; Dekker \& Siegel, 2013).

Transnational activities among the second generation will depend on ideas of nationalism and nation engagement, described by Glick Schiller and Fouron (2001) as 'longdistance nationalism'. For some scholars, the transnational links of both the first and the second generation help their integration (Portes, 1992). This integration allows in turn transnational ties to continue over time (Kasinitz, 2008) whereas, for other authors, these transnational ties might be a reaction to racism and stereotyping in the host country (Glick Schiller \& Fouron, 2001) or lack of rights (Ambrosetti, Cela, \& Fokkema, 2013). In other words, transnational relations and activities of migrants need to be considered if we are to have a more comprehensive understanding of integration (Dahinden, 2012; Glick Schiller, Basch, \& Szanton Blanc, 1992; Portes et al., 1999).

Literature specifically on refugees' transnational behaviour is rare. Research with refugees suggests that transnational activities will vary according to their aspirations for return, their relationship with the receiving nation-state, their transnational capacity (such as financial resources), their obligations based on kinship and the closeness of their kinship ties in the sending country (Al-Ali \& Koser, 2002; Bloch, 2008; Chimienti, Counilh, \& Ossipow, 2019; Hammond, 2013; Horst, 2008; Lindley, 2010).

\section{Identity and belonging}

Second-generation descendants of migrants are often described in the literature as having fractured or fluid identities, multiple belongings and contradictory notions of home. They tend, however, to talk about their self-identity more openly than their parents do (Kasinitz et al., 2008). For refugees, negotiating and renegotiating the old and the new homes can also include an aspiration to return 'home' or the realisation that home as they knew it no longer exists and cannot be revisited (Gilmartin, 2008; Sirriyeh, 2010; Staeheli \& Nagel, 2006). However, home is not only a physical place, and studies on transnationalism and translocalism highlight the complexities between mobility, emplacement, belonging and engagement in transnational social spaces (Al-Ali, Black, \& Koser, 2001; Glick Schiller et al., 1992, 1995; Levitt, 2009; Portes et al., 1999).

States play a role in facilitating or preventing pathways to belonging through integration, settlement and citizenship policies (Gilmartin, 2008; Kofman, 2005; Wanner, 2004). Moreover, Valentine et al. note that identity '...is also dependent, at least in part, on an individual's identity being recognised or accepted by a wider community...' (Valentine, Sporton, \& Nielsen, 2009, p. 236). Thus identity is relational and interactive, not something developed by individuals in isolation; experiences of inclusion, exclusion and racism shape identities and explain why some second generation do not feel to 'fit in' whilst they succeed at school and professionally (see Ossipow, Counilh, \& Chimienti, 2019).

\section{Mapping the special issue}

Our special issue includes four articles that consider the classical foci of studies on integration: education, racism, transnational ties and feelings of belonging. These articles will contribute to the literature on second-generation migrants by exploring the specific 
impact of refugee backgrounds on these issues and comparing the situation between the different groups studied.

The first two articles, by Crul, Lelie, Biner, Bunar, Keskiner, Kokkali, Schneider and Shuayb (2019) and by Koehler and Schneider (2019) analyse the educational systems and school success of the children of refugees. Their research provides an analysis of the first years in exile as it includes children who were not born in the country of residence (and who correspond therefore to those categorised as the 1.5 generation), who were still minors at the time of the research and who were still in a situation of legal uncertainty while waiting for an answer to their asylum request.

Crul, et al. (2019) compare how schools receive refugee children between countries inside Europe (Sweden, Germany and Greece) and outside Europe (Turkey and Lebanon). Whilst most of the literature on the children of refugees and their education has focused on welcoming issues and their immersion in international classes, this article aims to examine the effects of each educational system on the school careers of these children. Its focus on institutional arrangements in education and how these may influence school careers and final outcomes. The authors show that school systems vary between those that have no specific measures and those that create a parallel system for refugee children arguing that it is necessary to have both regular and parallel classes. The institutional arrangements which allow better access for refugee children and equal opportunities are those where the time spent in parallel systems such as immersion classes is as short as possible, where the transfer to 'regular' classes occurs with the second language support and therefore with the support of additional teachers (mixing regular and parallel classes) and where there are second-chance routes through adult education. The paper also highlights the impact of welfare systems and national models of integration on institutional arrangements for refugees and their children's educational careers. These systems vary, with Sweden offering the most inclusive system with the same access to provision for refugee children as for everyone else in society. Moreover, the time in immersion classes in Sweden is as short as possible and the inclusion in mainstream classes is supported by additional teachers and second language support.

Koehler and Schneider's article also compares school systems, questioning whether the educational arrangements made in the past for children from non-native speaking immigrant families - e.g. labour migrants - have improved and are now adapted to the current educational integration of the children of refugees. Drawing on previous research on second-generation migrants they want to find out which lessons from the past have been learnt or should be listened to more carefully. Their research focuses on seven countries in Europe (Belgium, Bulgaria, Germany, Greece, the Netherlands, Sweden, and the UK) and is based on both primary and secondary data. The article reveals that, despite several improvements, schools are still not well enough prepared, in particular for the children of refugees. However, it seems to be accepted, today, across all systems, that education is a universal right that ranks higher than laws concerning foreigners. This paper also illustrates the many variations between educational systems, with some providing the minimal requirements and others, such as the Swedish one, aiming to enable successful trajectories at school for all. It shows the importance of quick immersion into regular classes and to enable access to education after 16-18 years old for students who discover later their interest into education. The paper 
concludes by highlighting that one recurring mistake made by governments and school administrations is the tendency to consider migration as temporary and therefore to provide only 'ad-hoc' measures in emergency situations instead of permanent measures.

The other two papers draw on cross-national comparative research carried out with the European-born adult children of refugees from Tamil, Vietnamese, Turkish and Kurdish backgrounds living in Geneva, London or Paris (see also Bloch et al., 2016). They provide evidence on long-term trajectories as the empirical research focused on second generation refugees of adult age.

Bloch and Hirsch (2018) compare the transnational activities and social ties of members of the second generation from different backgrounds highlighting similarities and differences between three groups that can be partly explained by the exile country context. For instance, the Kurdish community is more involved in political transnationalism in the UK relating to Kurdish politics and the Kurdish national project. This political consciousness has been passed down inter-generationally and through the active participation in community based organisations. Bloch and Hirsch (2018) also show the inter-generational differences: whilst the second generation remit less than their parents, some engage in social, cultural and faith-based transnational activities but these vary within and between groups. The paper shows that the analysis of transnational activities and 'simultaneous embeddedness' in both homeland country and country of residence requires a more-nuanced scrutiny than just an intersectional analysis considering experiences of race, class and gender: their parents' histories and narratives of pre-migration experiences and exile clearly impact on their children.

The article by Ossipow, Counilh and Chimienti (2019) focuses on the situation in the country of residence - Switzerland. It explores the experiences of racism and racialisation faced by the children of refugees with Kurdish, Tamil and Vietnamese backgrounds. The article analyses, on the one hand, the context of racialisation and racism and, on the other hand, the reaction of those who are racialised and subjected to racism. It shows that most of the children of refugees minimise their experiences of racism and racialisation. When some do recount experiences of racism they generally refer to the micro level of individual interactions rather than to group or institutional level. They also tend to explain cases of discrimination at school - such as teachers who tried to orient them to vocational instead of tertiary pathways despite sufficient results which would enable them formally to follow a more demanding route - in terms of class rather than in terms of race, ethnicity or refugee background. Through this denial or minimisation strategy, the children of refugees also want to underline their success. They want to be seen as powerful individuals, not as victims. The authors explain these attitudes using Goldberg's concept (Goldberg, 2006) of "political racelessness", a concept for the analysis of attitudes which push towards the invisibility and inaudibility of racism consciousness and complaints.

\section{Conclusion}

Starting with the hypothesis that the particular experiences of refugee parents have an impact on their children, this special issue provides ample evidence for that assumption. Whilst their refugee background has a clear impact on their experiences and transnational activities and, for some, their professional choices (see Bloch et al., 2016), 
the papers also demonstrate variability of experiences and how these relate to different country experiences - both sending and receiving countries. Moreover the papers show that the notion of integration is complex and that an appropriate theoretical framework has to consider individual and contextual factors. Along this line both Crul et al. (2019) and Koehler and Schneider (2019) argue that institutional arrangements and support can make a great difference.

As refugees continue to arrive in Europe from all over the world, understanding the complexities of past and present, structure and agency, choice and constraint and how these will impact on experiences and life courses is an urgent task. The papers in this special issue set out to make a contribution, but there is still much work to be done.

\section{Endnotes}

${ }^{1}$ According to Rumbaut (2008a) these $11 \%$ represent 30 million US-born members of the second generation in 2006, of whom 17.4 million were under the age of 18 (https:// www.migrationpolicy.org/article/second-generation-united-states\#1). These $34.3 \%$ in Europe include $24.8 \%$ of second-generation migrants with EU origins and $9.5 \%$ with non-EU origins in 2014 (Eurostat http://ec.europa.eu/eurostat/statistics-explained/ index.php/Main_Page). The second generation includes the native-born with at least one parent foreign-born in the country of residence.

${ }^{2}$ https://www.service-public.fr/particuliers/vosdroits/F295, last consulted on 10 April 2019.

${ }^{3}$ Home Office, 2019.

${ }^{4}$ See comparable debates on categories such as 'migrants' (Dahinden, 2016; Favell 2014), 'refugees' (Crawley \& Skleparis, 2017), 'integration' (Korteweg, 2017) or 'migration background' (Elrick \& Schwartzman, 2015; Römhild, 2014).

${ }^{5}$ These include, among others: The Second Generation in Early Adulthood: A Decade-Long Panel (Portes \& Rumbaut, 2001); The Immigrant Second Generation in Metropolitan New York (ISGMNY) project (Kasinitz, 2008; Kasinitz, Mollenkopf, \& Waters, 2002, 2004; Kasinitz et al., 2008); the Immigration and Intergenerational Mobility in Metropolitan Los Angeles (IIMMLA) project (see, for instance, Rumbaut, 2008a, 2008b; Zhou \& Lee, 2007, Zhou, Lee, Vallejo, Tafoya-Estrada, \& Xiong, 2008); The Effectiveness of National Integration Strategies Towards Second-Generation Migrant Youth in a Comparative European Perspective project (EFNATIS) - carried out in eight EU countries in order to investigate 'the relationships between national policies on integration and the outcomes for the second generation' (Penn \& Lambert, 2009); The Children of Immigrants Longitudinal Survey in Four European Countries, i.e. Germany, the Neterlands, Sweden and England (CILS4EU: http://www.cils4.eu), The Integration of the European second generation in Europe Survey(TIES), which studied the integration of the children of immigrants at school and on the labour market in cities in eight European countries and revealed that an important number of the second generation were achieving a higher education (Crul et al., 2012; Crul \& Vermeulen, 2003); and the ELITES: Pathways to Success project, which studies the trajectories and intergenerational social mobility among second-generation Turkish elites and among their peers of non-immigrant ancestry in eight European cities (Crul, Keskiner, \& Lelie, 2017; Lang, Pott, \& Schneider, 2016, 2018). 


\section{Acknowledgements}

Two papers of this special issue are based on a collaborative research project conducted in Geneva, London and Paris between June 2014 and December 2015 by Alice Bloch \& Shirin Hirsch (University of Manchester) and by Laurence Ossipow, Anne-Laure Counilh \& Milena Chimienti (University of Applied Sciences Western Switzerland - HES-SO). We thank all the participants in the study. We thank Anne-Laure Counilh, Shirin Hirsch, Giovanna Tattolo, Elena Ambrosetti, Claudio Bolzman, Maurice Crul and Andreas Pott for their comments on this introduction.

\section{Authors' contributions}

This introduction was co-written by the four mentioned authors. All authors read and approved the final manuscript.

\section{Funding}

Two of the papers of this special issue were financed by the Swiss Network for International Studies. [project number 13-6401].

\section{Availability of data and materials}

https://snis.ch/project/children-of-refugees-in-europe/?et_fb=1

\section{Competing interests}

The authors declare that they have no competing interests.

\section{Author details}

${ }^{1}$ University of Applied Sciences and Arts Western Switzerland - School of Social Work, HESSO-GE/HETS, 28, rue Prévost-Martin, P.O. Box 80, 1211 Geneva 4, Switzerland. ${ }^{2}$ Sociology Department, School of Social Sciences, The University of Manchester, Oxford Rd, Manchester M13 9PL, UK. ${ }^{3}$ Centre d'études et de recherches internationales CERI-UMR / CNRS - Sciences Po Paris, 56 rue Jacob, 75006 Paris, France.

Received: 28 December 2017 Accepted: 30 May 2019

Published online: 11 September 2019

\section{References}

Al-Ali, N., Black, R., \& Koser, K. (2001). Refugees and transnationalism: The experience of Bosnians and Eritreans in Europe. Journal of Ethnic and Migration Studies, 27(4), 615-634.

Al-Ali, N., \& Koser, K. (Eds.) (2002). New approaches to migration?: transnational communities and the transformation of home. London: Routledge.

Alba, R. D., \& Nee, V. (2003). Remaking the American mainstream: Assimilation and contemporary immigration. Cambridge: Harvard Univ. Press.

Albertini, A., Knauth, B., Kraszewska, K., \& Thorogood, D. (2011). Migrants in Europe. A statistical portrait of the first and second generation. Luxembourg: Eurostat.

Alitolppa-Niitamo, A. (2004). Somali youth in the context of schooling in metropolitan Helsinki: A framework for assessing variability in educational performance. Journal of Ethnic and Migration Studies, 30(1), 81-106. https://doi.org/10.1080/ 1369183032000170187.

Ambrosetti, E., Cela, E., \& Fokkema, T. (2013). The differential impact of the legal status of migrants in Italy on transnationalism: Just a matter of time and integration? Journal of Mediterranean Studies, 22(1), 33-60.

Amelina, A., \& Faist, T. (2008). Turkish migrant associations in Germany: Between integration pressure and transnational linkages. Revue Européenne des Migrations Internationales, 24(2), 91-120. https://doi.org/10.4000/remi.4542.

Audebert, C.., \& Doraï, M. K. (2010). Migration in a globalised world new research issues and prospects. Amsterdam; Manchester: Amsterdam University Press; Manchester University Press [distributor]. Retrieved from http://www.imiscoe.org/docmanbooks/268-audebert-and-dorai-2010/file

Bilgili, Ö., Huddleston, T., \& Joki, A.-L. (2015). The dynamics between integration policies and outcomes: A synthesis of the literature (integration policies: Who benefits. The development and use of indicators in integration debates). Retrieved from http://mipex.eu/sites/default/files/downloads/files/mipex_literature-review_the-dynamics-between-integrationpolicies-and-outcomes.pdf

Bloch, A. (2008). Refugees in the UK labour market: The conflict between economic integration and policy-led labour market restriction. Journal of Social Policy, 37(1), 21-36. https://doi.org/10.1017/S004727940700147X.

Bloch, A., Chimienti, M., Counilh, A.-L., Hirsch, S., Tattolo, G., Ossipow, L., \& Wihtol de Wenden, C. (2016). The children of refugees in Europe: aspirations, social and economic lives, identity and transnational linkages (Working Paper). Final report. Geneva: SNIS. Retrieved from https://snis.ch/wp-content/uploads/2019/05/6401_final_wp_5_children_of_refugees_cross_ analysis_working_paper.pdf

Bloch, A., \& Hirsch, S. (2018). Inter-generational transnationalism: the impact of refugee backgrounds on second generation. Comparative Migration Studies, 6. https://doi.org/10.1186/s40878-018-0096-0

Bloch, A., \& Hirsch, S. (2017). The educational experiences of the second generation from refugee backgrounds. Journal of Ethnic and Migration Studies, 43(13), 2131-2148. https://doi.org/10.1080/1369183X.2017.1286972.

Bloch, A., Neal, S., \& Solomos, J. (2013). Race, multiculture and social policy. Basingstoke: Palgrave Macmillan.

Bolzman, C., Bernardi, L., \& Le Goff, J.-M. (2017). Introduction : Situating children of migrants across borders and origins. In C. Bolzman, L. Bernardi, \& J.-M. Le Goff (Eds.), Situating children of migrants across borders and origins. A methological overview, (pp. 1-21). The Netherlands: Springer Open.

Bolzman, C., Fibbi, R., \& Vial, M. (2003). Secondas-Secondos. Le processus d'intégration des jeunes adultes issus de la migration espagnole et italienne en Suisse [Secondas-secondos. The process of integrating young adults from Spanish and Italian migration into Switzerland]. Zurich: Seismo.

Boyd, M. (2002). Educational attainments of immigrant offspring: Success or segmented assimilation? International Migration Review, 36(4), 1037-1060. https://doi.org/10.1111/j.1747-7379.2002.tb00117. 
Brubaker, W. R. (1992). Citizenship struggles in soviet successor states. International Migration Review, 26(2), 272-290.

Burnett, A., \& Peel, M. (2001). Health needs of asylum seekers and refugees. BMJ (Clinical Research Ed.), 322(7285), 544-547.

Castles, S. (2004). Why migration policies fail. Ethnic and Racial Studies, 27(2), 205-227.

Castles, S., \& Miller, M. J. (2003). The age of migration. Guilford Press.

Cattacin, S., Fibbi, R., \& Wanner, P. (2016). La nouvelle seconde génération. Introduction au numéro special [The new second generation. Introduction to special issue]. Swiss Journal of Sociology, 42(2), 209-217.

Child, I. L. (1943). Italien or American?: The second generation in conflict. Yale: Yale University Press.

Chimienti, M., Counilh, A. L., \& Ossipow, L. (2019). How do children of refugees' feelings affect their transnational ties with the ancestral homeland? In A. Bloch, \& G. Donna (Eds.), Forced migration: Current issues and debates, (pp. 145-162). London: Routledge.

Crawley, H., \& Skleparis, D. (2017). Refugees, migrants, neither, both: Categorical fetishism and the politics of bounding in Europe's 'migration crisis'. Journal of Ethnic and Migration Studies, (0), 1-17. https://doi.org/10.1080/1369183X.2017.1348224.

Crettaz, E., \& Jacot, C. (2014). Do family policies matter for educational outcomes?: Patterns of educational mobility and family services in Europe. European Societies, 16(5), 645-665. https://doi.org/10.1080/14616696.2014.946070.

Crul, M., Keskiner, E., \& Lelie, F. (2017). The upcoming new elite among children of immigrants: A cross-country and crosssector comparison. Ethnic and Racial Studies, 40(2), 209-229. https://doi.org/10.1080/01419870.2017.1245432.

Crul, M., Lelie, F., Biner, Ö., Bunar, N., Keskiner, E., Kokkali, I., Schneider, J., \& Shuayb, M. (2019). How the different policies and school systems affect the inclusion of Syrian refugee children in Sweden, Germany, Greece, Lebanon and Turkey. Comparative Migration Studies, 7. https://doi.org/10.1186/s40878-018-0110-6

Crul, M., \& Mollenkopf, J. H. (Eds.) (2012). The changing face of world cities: The second generation in Western Europe and the United States. New York: Russell Sage Foundation.

Crul, M., \& Schneider, J. (2009). The second generation in Europe. Education and the transition to the labour market. TIES Policy Brief for Stakeholders.

Crul, M., \& Schneider, J. (2010). Comparative integration context theory: Participation and belonging in new diverse European cities. Ethnic and Racial Studies, 33(7), 1249-1268. https://doi.org/10.1080/01419871003624068.

Crul, M., Schneider, J., \& Lelie, F. (2012). The European second generation compared: Does the integration context matter. Amsterdam: Amsterdam University Press.

Crul, M., \& Vermeulen, H. (2003). The second generation in Europe. International Migration Review, 37(4), 965-986.

Crul, M., \& Vermeulen, H. (2006). Imigration, education, and the Turkish second generation in five European nations. A comparative study. In C. A. Parsons, \& T. M. Smeeding (Eds.), Immigration and the transformation of Europe, (pp. 236-250). Cambridge: Cambridge University Press.

Dahinden, J. (2012). Transnational belonging, non-ethnic forms of identification and diverse mobilities: Rethinking migrant integration? In M. Messer, R. Schroeder, \& R. Wodak (Eds.), Migration: Interdisciplinary perspectives, (pp. 117128). Wien: Springer.

Dahinden, J. (2016). Migration im Fokus? Plädoyer für eine reflexive Migrationsforschung [Migration in focus? Plea for reflexive migration research]. Migration und integration - wissenschaftliche Perspektiven aus Österreich, (pp. 11-29). Göttingen: VeR unipress GmbH Jahrbuch 3/2016

Davies, M., \& Webb, E. (2000). Promoting the psychological well-being of refugee children. Clinical Child Psychology and Psychiatry, 5(4), 541-554. https://doi.org/10.1177/1359104500005004008.

Dekker, B., \& Siegel, M. (2013). Transnationalism and integration : Complements or substitutes? (UNU-MERIT Working Papers). Maastricht Graduate School of Governance.

Dustmann, C., Frattini, T., \& Lanzara, G. (2012). Educational achievement of second generation immigrants : An international comparison. Economic Policy, 27(69), 78-119.

Elrick, J., \& Schwartzman, L. F. (2015). From statistical category to social category: Organized politics and official categorizations of 'persons with a migration background' in Germany. Ethnic and Racial Studies, 38(9), 1539-1556. https:// doi.org/10.1080/01419870.2014.996240.

Faist, T., Schmidt, K., \& Ulbricht, C. (2016). Inclusion, Exclusion, and Citizenship: European Practices. In M. Ambrosini (Ed.), Europe - No Migrant's Land? ISPI. Retrieved from https://www.ispionline.it/it/EBook/MIGRATION\%202016/Europe-nomigrants-land.pdf

Farley, R., \& Alba, R. (2002). The new second generation in the United States. International Migration Review, 36(3), 669-701. https://doi.org/10.1111/j.1747-7379.2002.tb00100.x.

Favell, A. (2014). Immigration, integration and mobility: New agendas in migration studies: Essays 1998-2014. Colchester: ECPR Press.

Feliciano, C. (2005). Does selective migration matter? Explaining ethnic disparities in educational attainment among immigrants' children. International Migration Review, 39(4), 841-871.

Fibbi, R., Lerch, M., \& Wanner, P. (2006). Unemployment and discrimination against youth of immigrant origin in Switzerland: When the name makes the difference. Journal of International Migration and Integration / Revue de L'integration et de La Migration Internationale, 7(3), 351-366. https://doi.org/10.1007/s12134-006-1017-x.

Fibbi, R., Lerch, M., \& Wanner, P. (2007). Naturalisation and socio-economic characteristics of youth of immigrant descent in Switzerland. Journal of Ethnic and Migration Studies, 33(7), 1121-1144. https://doi.org/10.1080/ 13691830701541655.

Gagné, N., \& Neveu, C. (Eds.) (2009). Citoyennetés [Citizenships]. Anthropologie et societies, 33(2), 7-24.

Gans, H. J. (1992). Second generation decline: Scenarios for the economic and ethnic futures of the post 1965 American immigrants. Ethnic and Racial Studies, 15(2), 173-192. https://doi.org/10.1080/01419870.1992.9993740.

Gilmartin, M. (2008). Migration, identity and belonging. Geography Compass, 2(6), 1837-1852. https://doi.org/10.1111/j.17498198.2008.00162.x

Glick Schiller, N., Basch, L., \& Blanc-Szanton, C. (1995). From immigrant to transmigrant: Theorizing transnational migration. Anthropological Quarterly, 68(1), 48-63.

Glick Schiller, N., Basch, L., \& Szanton Blanc, C. (1992). Transnationalism : A new analytic framework for understanding migration. Annals of the New York Academy of Science, 645, 1-24.

Glick Schiller, N., \& Fouron, G. E. (2001). Georges woke up laughing: Long-distance nationalism and the search for home. Durham: Duke University Press. 
Goldberg, D. T. (2006). Racial Europeinization. Ethnic and Racial Studies, 29(2), 331-364. https://doi.org/10.1080/ 01419870500465611.

Gomensoro, A., \& Bolzman, C. (2016). Les trajectoires éducatives de la seconde génération : Quel déterminisme des filières du secondaire I et comment certains jeunes le surmontent? [Educational pathways of the second generation. What kind of determinism in lower secondary educational tracking and how some youngsters overcome it?]. Revue Suisse de Sociologie, 42(2), 289-308.

Gordon, M. (1964). Assimilation in American life: The role of race, religion, and national origins. New York: Oxford University Press.

Greenman, E., \& Xie, Y. (2008). Is assimilation theory dead? The effect of assimilation on adolescent well-being. Social Science Research, 37(1), 109-137. https://doi.org/10.1016/j.ssresearch.2007.07.003.

Haikkola, L. (2011). Making connections: Second generation children and the transnational field of relations. Journal of Ethnic and Migration Studies, 37(8), 1201-1217. https://doi.org/10.1080/1369183X.2011.590925.

Hammond, L. (2013). Somali transnational activism and integration in the UK: Mutually supporting strategies. Journal of Ethnic and Migration Studies, 39(6), 1001-1017. https://doi.org/10.1080/1369183X.2013.765666.

Heath, A. F., \& Cheung, S. Y. (2007). Unequal chances: Ethnic minorities in Western labour markets. British Academy.

Heptinstall, E., Sethna, V., \& Taylor, E. (2004). PTSD and depression in refugee children: Associations with pre-migration trauma and post-migration stress. European Child \& Adolescent Psychiatry, 13(6), 373-380. https://doi.org/10.1007/s00787-004-0422-y.

Hirschman, C. (2001). The educational enrollment of immigrant youth: A test of the segmented-assimilation hypothesis. Demography, 38(3), 317-336.

Home Office (2019). Form MN1: guidance. Guidance to register a child under 18 as a British citizen. Retrieved 10 April 2019 from https://www.gov.uk/government/publications/form-mn1-guidance

Horst, C. (2008). The transnational political engagements of refugees: Remittance sending practices amongst Somalis in Norway: Analysis. Conflict, Security \& Development, 8(3), 317-339. https://doi.org/10.1080/14678800802323340.

Joppke, C. (1999). How immigration is changing citizenship: A comparative view. Ethnic and Racial Studies, 22(4), 629-652. https://doi.org/10.1080/014198799329323.

Kasinitz, P. (2008). Becoming American, becoming minority, getting ahead: The role of racial and ethnic status in the upward mobility of the children of immigrants. Annals of the American Academy of Political and Social Science, 620, 253-269.

Kasinitz, P., Mollenkopf, J., \& Waters, M. C. (2002). Becoming American/becoming New Yorkers: Immigrant incorporation in a majority minority city. International Migration Review, 36(4), 1020-1036.

Kasinitz, P., Mollenkopf, J., \& Waters, M. C. (Eds.) (2004). Becoming New Yorkers: Ethnographies of the new second generation. Russell Sage Foundation. Retrieved from http://www.jstor.org/stable/10.7758/9781610443289

Kasinitz, P., Mollenkopf, J. H., Waters, M. C., \& Holdaway, J. (2008). Inheriting the city: The children of immigrants come of age. New York; Cambridge: Russell Sage Foundation; Harvard University Press.

King, R., Christou, A., \& Ahrens, J. (2011). 'Diverse Mobilities': Second-generation Greek-Germans engage with the homeland as children and as adults. Mobilities, 6(4), 483-501. https://doi.org/10.1080/17450101.2011.603943.

Koehler, C., \& Schneider, J. (2019). Young refugees in education: the particular challenges of school systems in Europe. Comparative Migration Studies, 7. https://doi.org/10.1186/s40878-019-0129-3

Kofman, E. (2005). Citizenship, migration and the reassertion of national identity. Citizenship Studies, 9(5), 453-467. https://doi. org/10.1080/13621020500301221.

Korteweg, A. C. (2017). The failures of 'immigrant integration': The gendered racialized production of non-belonging. Migration Studies, 5(3), 428-444. https://doi.org/10.1093/migration/mnx025.

Kroneberg, C. (2008). Ethnic communities and school performance among the new second generation in the United States: Testing the theory of segmented assimilation. The Annals of the American Academy of Political and Social Science, 620(1), 138-160. https://doi.org/10.1177/0002716208322714.

Lang, C., Pott, A., \& Schneider, J. (2016). Unwahrscheinlich erfolgreich. Sozialer Aufstieg in der Einwanderungsgesellschaft [Unlikely to succeed. Social mobility in the society of immigration]. (IMIS-Beiträge, Heft 49). Osnabrück: IMIS.

Lang, C., Pott, A., \& Schneider, J. (2018). Erfolg nicht vorgesehen. Sozialer Aufstieg in der Einwanderungsgesellschaft - und was ihn so schwer macht. [Success not provided: Social mobility in society of immigration - and what makes it so difficult]. Münster-New York: Waxman.

Levitt, P. (2009). Roots and routes: Understanding the lives of the second generation transnationally. Journal of Ethnic and Migration Studies, 35(7), 1225-1242. https://doi.org/10.1080/13691830903006309.

Lindley, A. (2010). The early morning phonecall: Somali refugees' remittances. New York: Berghahn Books.

Lustig, S. L., Kia-Keating, M., Knight, W. G., Geltman, P., Ellis, H., Kinzie, J. D., .. Saxe, G. N. (2004). Review of child and adolescent refugee mental health. Journal of the American Academy of Child \& Adolescent Psychiatry, 43(1), 24-36. https:// doi.org/10.1097/00004583-200401000-00012.

McBrien, L. (2005). Educational needs and barriers for refugees students in the United States: A review of the literature. Review of Educational Research, 75(3), 329-364. https://doi.org/10.3102/00346543075003329.

Mckay, D. (2007). 'Sending dollars shows feeling' - Emotions and economies in Filipino migration. Mobilities, 2(2), 175-194. https://doi.org/10.1080/17450100701381532.

Meurs, D., Pailhé, A. \& Simon, P. (2006). Persistance des inégalités entre générations liées à limmigration : l'accès à l'emploi des immigrés et de leurs descendants en France [Persistence of intergenerational inequalities linked to immigration: Access to employment for immigrants and their descendants in France]. Population, 61(5), 763-801. https://doi.org/10.3917/popu.605.0763.

Ossipow, L., Counilh, A-L., \& Chimienti, M. (2019). Racialization in Switzerland: experiences of children of refugees from Kurdish, Tamil and Vietnamese backgrounds. Comparative Migration Studies, 7. https://doi.org/10.1186/s40878-019-0117-7

Park, R. E., \& Burgess, E. W. (1970). Introduction to the science of sociology. Chicago: University of Chicago Press. (Original work published 1921).

Penn, R., \& Lambert, P. (2009). Children of international migrants in Europe: Comparative perspectives. Basingstoke: Palgrave.

Portes, A. (1992). Globalization from below: The rise of transnational communities. Princeton: Princeton University Press.

Portes, A., \& Fernández-Kelly, P. (2008). No margin for error: Educational and occupational achievement amoung disadvantaged children of immigrants. Annals of the American Academy of Political and Social Science, 620(1), 12-36. https://doi.org/10.1177/0002716208322577. 
Portes, A., Guarnizao, L., \& Landolt, P. (1999). The study of transnationalism: Pitfalls and promise of an emergent research field. Ethnic and Racial Studies, 22(2), 217-237. https://doi.org/10.1080/014198799329468.

Portes, A., \& Rumbaut, R. G. (2001). Legacies: The story of the immigrant second generation. Berkeley: University of California Press.

Portes, A., \& Zhou, M. (1993). The new second generation: Segmented assimilation and its variants. The Annals of the American Academy of Political and Social Science, 530(1), 74-96.

Robinson, V., Andersson, R., \& Musterd, S. (2003). Spreading the 'burden'? A review of policies to disperse asylum seekers and refugees. Bristol: Policy Press.

Römhild, R. (2014). Diversität?! Postethnische Perspektiven für eine reflexive Migrationsforschung [Diversity ?! Post-Ethnic Perspectives for Reflexive Migration Research]. Kultur, Gesellschaft, migration, (pp. 255-270). Wiesbaden: Springer VS. https://doi.org/10.1007/978-3-658-03626-3_10.

Rumbaut, R. (2008a). Reaping what you sew: Immigration, youth, and reactive ethnicity (SSRN scholarly paper no. ID 1878106). Rochester: Social Science Research Network.

Rumbaut, R. G. (2008b). The coming of the second generation : Immigration and ethnic mobility in Southern California. Annals of the American Academy of Political and Social Science, 620, 196-236 (Exceptional Outcomes: Achievement in Education and Employment amoung Children of Immigrants).

Schierup, C.-U., Hansen, P., \& Castles, S. (2006). Migration, citizenship, and the European welfare state: A European dilemma. Oxford University Press. https://doi.org/10.1093/0198280521.001.0001

Silberman, R., Alba, R., \& Fournier, I. (2007). Segmented assimilation in France? Discrimination in the labour market against the second generation. Ethnic and Racial Studies, 30(1), 1-27. https://doi.org/10.1080/01419870601006488.

Simon, P. (2003). France and the unknown second generation: Preliminary results on social mobility. International Migration Review, 37(4), 1091-1119. https://doi.org/10.1111/j.1747-7379.2003.tb00171.x.

Sirriyeh, A. (2010). Home journeys: Im/mobilities in young refugee and asylum-seeking women's negotiations of home. Childhood, 17(2), 213-227. https://doi.org/10.1177/0907568210365667.

Smith, J. (2003). Assimilation across the Latino generations. American Economic Review, 93(2), 315-319.

Smith, W. C. (1928). Changing personality traits of second generation Orientals in America. American Journal of Sociology, 33(6), 922-929.

Solomos, J. (1986). Trends in the political analysis of racism. Political Studies, 34(2), 313-324. https://doi.org/10.1111/j.14679248.1986.tb01599.x

Solomos, J. (2003). Race and racism in Britain, (3rd ed., ). Basingstoke; New York: Palgrave Macmillan.

Staeheli, L. A., \& Nagel, C. R. (2006). Topographies of home and citizenship: Arab-American activists in the United States. Environment and Planning A, 38(9), 1599-1614. https://doi.org/10.1068/a37412.

Suárez-Orozco, C., Yoshikawa, H., Teranishi, R., \& Suarez-Orozco, M. (2011). Growing up in the shadows: The developmental implications of unauthorized status. Harvard Educational Review, 81(3), 438-472.

Thomas, W. I., \& Znaniecki, F. (1918). The polish peasant in Europe and America: Monograph of an immigrant group. Boston: Badger.

Thomson, M., \& Crul, M. (2007). The Second Generation in Europeand the United States: How is the Transatlantic Debate Relevant for Further Research on theEuropean Second Generation? Journal of Ethnic and Migration Studies, 33(7), 1025041. https://doi.org/10.1080/13691830701541556.

Thurairajah, K. (2017). The case of the Sri Lankan Tamil diaspora and homeland: A shared ethnic identity? Studies in Ethnicity and Nationalism, 17(1), 115-132. https://doi.org/10.1111/sena.12222.

Valentine, G., Sporton, D., \& Nielsen, K. B. (2009). Identities and belonging: A study of Somali refugee and asylum seekers living in the UK and Denmark. Environment and Planning D: Society and Space, 27(2), 234-250. https://doi.org/10.1068/d3407.

Virdee, S. (2010). The continuing significance of 'race': Racism, contentious antiracist politics and labour markets in contemporary capitalism. In A. Bloch, \& J. Solomos (Eds.), Race and ethnicity in the 21st century. Basingstoke: Palgrave Macmillan.

Waldinger, R. (2007). Did manufacturing matter? The experience of yesterday's second generation: A reassessment. International Migration Review, 41(1), 3-39. https://doi.org/10.1111/j.1747-7379.2007.00055.x.

Waldinger, R., \& Feliciano, C. (2004). Will the new second generation experience 'downward assimilation'? Segmented assimilation re-assessed. Ethnic and Racial Studies, 27(3), 376-402. https://doi.org/10.1080/01491987042000189196.

Wanner, P. (2004). Migration und integration : Ausländerinnen und Ausländer in der Schweiz. Neuchâtel: Bundesamt für Statistik.

Wessendorf, S. (2007). 'Roots migrants': Transnationalism and 'return' among second-generation Italians in Switzerland. Journal of Ethnic and Migration Studies, 33(7), 1083-1102.

Wihtol de Wenden, C. (2005). Seconde génération : le cas français. [Second generation: The French case]. In R. Leveau, \& K. Mohsen-Finan (Eds.), Musulmans de France et d'Europe, [Muslims of France and Europe], (pp. 7-19). Paris: CNRS Editions.

Yoshikawa, H., \& Kalil, A. (2011). The effects of parental undocumented status on the developmental contexts of young children in immigrant families. Child Development Perspectives, 5(4), 291-297. https://doi.org/10.1111/j.1750-8606.2011.00204.x.

Zhou, M., \& Lee, J. (2007). Becoming ethnic or becoming American? Du Bois Review: Social Science Research on Race, 4(1), 189-205. https://doi.org/10.1017/S1742058X07070105.

Zhou, M., Lee, J., Vallejo, J. A., Tafoya-Estrada, R., \& Xiong, Y. S. (2008). Success attained, deterred, and denied: Divergent pathways to social mobility in Los Angeles's new second generation. The Annals of the American Academy of Political and Social Science, 620(1), 37-61. https://doi.org/10.1177/0002716208322586.

Zhou, M., \& Xiong, Y. S. (2005). The multifaceted American experiences of the children of Asian immigrants: Lessons for segmented assimilation. Ethnic and Racial Studies, 28(6), 1119-1152. https://doi.org/10.1080/01419870500224455.

\section{Publisher's Note}

Springer Nature remains neutral with regard to jurisdictional claims in published maps and institutional affiliations. 